\title{
A case-control analysis of oral contraceptive use and breast cancer subtypes in the African American Breast Cancer Epidemiology and Risk Consortium
}

Traci N Bethea ${ }^{{ }^{*},}$, Lynn Rosenberg ${ }^{1}$, Chi-Chen Hong ${ }^{2}$, Melissa A Troester ${ }^{3}$, Kathryn L Lunetta ${ }^{4}$, Elisa V Bandera ${ }^{5}$, Pepper Schedin ${ }^{6}$, Laurence N Kolonel, Andrew F Olshan ${ }^{3}$, Christine B Ambrosone ${ }^{2}$ and Julie R Palmer ${ }^{1}$

\begin{abstract}
Introduction: Recent oral contraceptive (OC) use has been consistently associated with increased risk of breast cancer, but evidence on specific breast cancer subtypes is sparse.

Methods: We investigated recency and duration of OC use in relation to molecular subtypes of breast cancer in a pooled analysis of data from the African American Breast Cancer Epidemiology and Risk Consortium. The study included 1,848 women with estrogen receptor-positive (ER+) breast cancer, 1,043 with ER-negative (ER-) breast cancer (including 494 triple negative (TN) tumors, which do not have receptors for estrogen, progesterone, and human epidermal growth factor 2), and 10,044 controls. Multivariable polytomous logistic regression models were used to estimate odds ratios (ORs) and 95\% confidence intervals (Cls) for exposure categories relative to never use, controlling for potential confounding variables.
\end{abstract}

Results: OC use within the previous 5 years was associated with increased risk of ER+ (OR 1.46, 95\% Cl 1.18 to 1.81), ER- (OR 1.57, 95\% Cl 1.22 to 1.43), and TN (OR 1.78, 95\% Cl 1.25 to 2.53) breast cancer. The risk declined after cessation of use but was apparent for ER+ cancer for 15 to 19 years after cessation and for ER- breast cancer for an even longer interval after cessation. Long duration of use was also associated with increased risk of each subtype, particularly ER-.

Conclusions: Our results suggest that OC use, particularly recent use of long duration, is associated with an increased risk of ER+, ER-, and TN breast cancer in African American women. Research into mechanisms that explain these findings, especially the association with ER- breast cancer, is needed.

\section{Introduction}

A combined analysis of 54 studies observed a $24 \%$ increase in breast cancer risk for current use of oral contraceptives (OCs) and a 16\% increase in risk for $<5$ years since stopping OC use [1]; the increase largely disappeared within 10 years after cessation. However, the length of time during which risk remains elevated is uncertain because few studies have assessed long intervals since stopping $[2,3]$. Subsequent studies suggest that

\footnotetext{
* Correspondence: tnb@bu.edu

'Slone Epidemiology Center at Boston University, 1010 Commonwealth Avenue, Boston, MA 02215-1201, USA

Full list of author information is available at the end of the article
}

long duration of OC use may also increase incident breast cancer risk [4-13]. These studies were based primarily on data from White women.

Gene expression studies have identified at least five intrinsic subtypes of breast cancer, and the most common clinical markers of breast cancer heterogeneity to date have been presence or absence of estrogen receptors (ERs) or progesterone receptors (PRs) and overexpression of human epidermal growth factor receptor 2 (HER2) [14]. Tumors that are ER- or triple negative (TN, defined as ER-/PR-/HER2-) have a lower 5-year survival than ER+ tumors [15,16], and are more common

\section{Biomed Central}

(c) 2015 Bethea et al.; licensee BioMed Central. This is an Open Access article distributed under the terms of the Creative Commons Attribution License (http://creativecommons.org/licenses/by/4.0), which permits unrestricted use, distribution, and reproduction in any medium, provided the original work is properly credited. The Creative Commons Public Domain Dedication waiver (http://creativecommons.org/publicdomain/zero/1.0/) applies to the data made available in this article unless otherwise stated. 
in African American women than in women of European ancestry [17-19].

Some risk factors, particularly hormone-related factors, appear to differentially associate with specific breast cancer subtype $[20,21]$, but evidence on OC use in relation to specific breast cancer subtypes is sparse and the findings are inconsistent [22]. Some studies find OC use to be associated with increased risk of ER+ and ER- breast cancer $[4,9]$, others with increased risk of ER- breast cancer only [23], and yet others observe an association solely for $\mathrm{ER}+$ breast cancer [24]. With respect to TN breast cancer, null results $[2,25]$ and an increased risk $[23,26]$ have been observed for OC use.

The objective of the present study was to investigate OC use in relation to molecular subtypes of breast cancer in African American women using data from a large consortium, the African American Breast Cancer Epidemiology and Risk (AMBER) project. In particular, we were able to assess long duration of $\mathrm{OC}$ use and recency of use, including intervals as long as 30 years or more since last use.

\section{Methods}

\section{Participating studies and data collection}

The AMBER Consortium has been described in detail elsewhere [27]. Its purpose is to provide enough data and samples for informative assessment of genetic and nongenetic factors in relation to breast cancer subtypes in African American women. The AMBER Consortium pools data from two large case-control studies, the Carolina Breast Cancer Study (CBCS) and the Women's Circle of Health Study (WCHS), and two large cohort studies, the Black Women's Health Study (BWHS) and the Multiethnic Cohort Study. Owing to missing data on recency of OC use, the Multiethnic Cohort Study was not included in this analysis, whereas data from the BWHS, the CBCS, and the WCHS were included.

The BWHS is a prospective cohort study of 59,000 African American women aged 21 to 69 years at baseline in 1995 [28]. Participants report data on OC use, other risk factors, and incident disease on biennial questionnaires. Questionnaire follow-up is complete for $80 \%$ of the baseline cohort through 2011. New diagnoses of cancer are self-reported on the follow-up questionnaires or identified through linkage with state cancer registries $[9,27]$. For each case, controls were selected from the pool of BWHS participants who had not developed breast cancer at the date of the case's breast cancer diagnosis (index date). Controls were frequency-matched to cases on 5-year age group, geographic region, and most recent questionnaire completed before the matched case diagnosis. Exposure and covariate data from that questionnaire and preceding questionnaires were used for the analysis.
The CBCS is a population-based case-control study of women aged 20 to 74 years in North Carolina conducted from 1993 through 2001 [29]. Breast cancer cases are identified through the North Carolina Central Cancer Registry. We used data from the first two phases, in which younger and African American cases were oversampled. Cases and controls were sampled using a modification of randomized recruitment. Controls younger than age 65 years were identified from Division of Motor Vehicle lists and controls age 65 years or older were identified from Health Care Financing Administration lists. Controls were frequency-matched to cases on age in 5-year age groups. Exposure and covariate data were collected through in-person interviews with reference to the year before diagnosis (cases) or interview date (controls) [29]. Response rates were $76 \%$ for cases and 55\% controls for recruitment of invasive breast cancer cases and matched controls, while response rates were $83 \%$ for cases and $65 \%$ controls for recruitment of in situ breast cancer cases and matched controls [29].

The WCHS is a population-based case-control study of women aged 20 to 75 years that began in New York in 2003 and currently enrolls participants in New Jersey only $[30,31]$. Breast cancer cases were identified through major hospitals in New York City and through the New Jersey Cancer Registry. Controls were identified through random digit dialing and through community-based recruitment and are frequency matched to cases on age in 5 -year age groups [31]. Exposure and covariate data were collected through in-person interviews with reference to the year before diagnosis (cases) or interview date (controls) [30]. Response rates were $78.7 \%$ in cases and $48.2 \%$ in controls [32].

Each study obtained informed consent from all participants and was approved by the relevant Institutional Review Boards, which are listed in Acknowledgements. Each study prepared a data file that included questionnaire data for a specified set of variables and pathology data from medical records or state cancer registry records. Data were harmonized at the data coordinating center with regular input from each study's principal investigator and data collection staff.

\section{Cases}

Incident cases of breast cancer (primary site codes C500 to C506, C508, and C509 in the International Classification of Diseases for Oncology, Third Edition), not including lobular carcinoma in situ (8520/2), phyllodes tumors (9020), or Paget's disease (8540/3), were confirmed through medical records and state cancer registries [33]. Immunohistochemistry results were obtained from hospital pathology records and cancer registry data, and were used to classify cases as ER+, ER-, and TN (ER-/PR-/ HER2-). ER data were available for $72 \%$ of cases and PR 
data were available for $69 \%$ of cases. Testing for HER2 has become routine more recently; therefore, HER2 data were available for only $49 \%$ of cases. There were no statistically significant differences between women with and without known receptor status by age or OC use. The proportion of ER- cases (Table 1) are similar to those observed for African American women in other data sources [34-36].

\section{Exposure variables}

\section{Oral contraceptive use}

The main exposures of interest for the present analyses were self-reported recency of OC use (years since last use) and duration of $\mathrm{OC}$ use. Women with a total duration of $\mathrm{OC}$ use of less than 1 year were considered to be never users. Recency of $\mathrm{OC}$ use was categorized as within the previous 5 years, 5 to 9 years ago, 10 to 14 years ago, 15 to 19 years ago, 20 to 24 years ago, 25 to 29 years ago, or $\geq 30$ years ago. Duration of OC use was categorized as 1 to 4 years, 5 to 9 years, 10 to 14 years, or $\geq 15$ years.

\section{Covariates}

Self-reported data were available on the following covariates: history of breast cancer in a first-degree female relative (mother, sister, or daughter), age at menarche, parity, age at first birth, lifetime duration of breastfeeding, menopausal status, age at menopause, menopausal female hormone use, height, weight, educational attainment, alcohol consumption, and cigarette smoking. For menopausal status, women who were still menstruating

Table 1 Characteristics of cases and controls in the AMBER Consortium, by included study (BWHS, CBCS, WCHS)

\begin{tabular}{|c|c|c|c|c|c|c|c|c|}
\hline & \multicolumn{2}{|l|}{ BWHS } & \multicolumn{2}{|l|}{ CBCS } & \multicolumn{2}{|l|}{ WCHS } & \multicolumn{2}{|l|}{ Total } \\
\hline & Cases & Controls & Cases & Controls & Cases & Controls & Cases & Controls \\
\hline \multicolumn{9}{|c|}{ Characteristics of breast cancer cases } \\
\hline Total & 1,313 & & 804 & & 774 & & 2,891 & \\
\hline $\mathrm{ER}+$ & $862(66)$ & & $436(54)$ & & $550(71)$ & & $1,848(64)$ & \\
\hline ER- & $451(34)$ & & $368(46)$ & & $224(29)$ & & $1,043(36)$ & \\
\hline Triple negative & $155(12)$ & & $210(26)$ & & $129(17)$ & & $494(17)$ & \\
\hline \multicolumn{9}{|l|}{ Age at diagnosis } \\
\hline$<40$ years & $98(8)$ & & $129(16)$ & & $87(11)$ & & $324(11)$ & \\
\hline 40 to 49 years & $385(29)$ & & $262(33)$ & & $209(27)$ & & $856(30)$ & \\
\hline 50 to 59 years & $456(35)$ & & $190(24)$ & & $277(36)$ & & $923(32)$ & \\
\hline$\geq 60$ years & $374(29)$ & & $223(28)$ & & $191(25)$ & & $788(27)$ & \\
\hline \multicolumn{9}{|c|}{ Oral contraceptive use among cases and controls } \\
\hline \multicolumn{9}{|l|}{ Ever use } \\
\hline No & $525(40)$ & $3,768(45)$ & $392(49)$ & $387(49)$ & $374(48)$ & $477(49)$ & $1,291(45)$ & $4,632(46)$ \\
\hline Yes & $788(60)$ & $4,522(55)$ & $412(51)$ & $398(51)$ & $400(52)$ & $492(51)$ & $1,600(55)$ & $5,412(54)$ \\
\hline \multicolumn{9}{|l|}{ Recency of OC use } \\
\hline$<5$ years ago & $182(14)$ & $950(11)$ & $68(8)$ & $52(7)$ & $64(8)$ & $73(8)$ & $314(11)$ & $1,075(11)$ \\
\hline 5 to 9 years ago & $68(5)$ & $464(6)$ & $44(5)$ & $32(4)$ & $36(5)$ & $48(5)$ & $148(5)$ & $544(5)$ \\
\hline 10 to 14 years ago & $77(6)$ & $499(6)$ & $53(7)$ & $59(8)$ & $39(5)$ & $37(4)$ & $169(6)$ & $595(6)$ \\
\hline 15 to 19 years ago & $105(8)$ & $620(7)$ & $95(12)$ & $85(11)$ & $45(6)$ & $52(5)$ & $245(8)$ & $757(8)$ \\
\hline 20 to 24 years ago & $108(8)$ & $692(8)$ & $90(11)$ & $102(13)$ & $47(6)$ & $65(7)$ & $245(8)$ & $859(9)$ \\
\hline 25 to 29 years ago & $124(9)$ & $653(8)$ & $35(4)$ & $46(6)$ & $55(7)$ & $79(8)$ & $214(7)$ & $778(8)$ \\
\hline$\geq 30$ years ago & $124(9)$ & $644(8)$ & $24(3)$ & $21(3)$ & $108(14)$ & $130(13)$ & $256(9)$ & $795(8)$ \\
\hline \multicolumn{9}{|l|}{ Duration of OC use } \\
\hline$<5$ years & $316(24)$ & $1,934(23)$ & $159(20)$ & $174(22)$ & $152(20)$ & $207(21)$ & $627(22)$ & $2,315(23)$ \\
\hline 5 to 9 years & $235(18)$ & $1,364(17)$ & $125(16)$ & $123(16)$ & $121(16)$ & $142(15)$ & $481(17)$ & $1,629(16)$ \\
\hline 10 to 14 years & $178(14)$ & $874(11)$ & $81(11)$ & $61(8)$ & $71(9)$ & $75(8)$ & $330(11)$ & $1,010(10)$ \\
\hline$\geq 15$ years & $59(4)$ & $350(4)$ & $47(6)$ & $40(5)$ & $56(7)$ & $68(7)$ & $162(6)$ & $458(5)$ \\
\hline
\end{tabular}

Data presented as $n$ (\%). Total percentages may not add up to $100 \%$ due to rounding. Excluding women with unknown duration of OC use and unknown ER status. ER status was unknown for 1,151 breast cancer cases: 90 in CBCS, 308 in WCHS, and 753 in BWHS. AMBER, African American Breast Cancer Epidemiology and Risk; BWHS, Black Women's Health Study; CBCS, Carolina Breast Cancer Study; ER, estrogen receptor; OC, oral contraceptive; WCHS, Women's Circle of Health Study. 
were classified as premenopausal. Women who had experienced a natural menopause or a hysterectomy with bilateral oophorectomy were classified as postmenopausal. Also classified as postmenopausal were women $(n=60)$ whose periods had stopped due to use of mediation, radiation, or chemotherapy for various health conditions other than breast cancer. Women who had a hysterectomy with retention of one or both ovaries were classified as premenopausal if their index age was less than or equal to the age at which $10 \%$ of women in their study had reached natural menopause, and as postmenopausal if their index age was greater than or equal to the age at which $90 \%$ of women in their study had reached natural menopause; otherwise, these participants were classified as having unknown menopausal status.

\section{Data analysis}

Polytomous logistic regression models were used to calculate odds ratios (ORs) and 95\% confidence intervals (CIs) for the relation of measures of OC use to ER+ and ER- breast cancer risk. For TN breast cancer risk, polytomous models had three outcomes: TN, ER+, and ER-/not TN. We controlled for age (continuous), study (CBCS, WCHS, BWHS), time period of case diagnosis/ control index date (1993 to 1998, 1999 to 2005, 2006 to 2013), family history of breast cancer (yes, no), age at menarche $(<12,12$ to $13, \geq 14$ years), parity $(0,1,2, \geq 3$ births), age at first birth ( $<20,20$ to $24, \geq 25$ years), lactation (never, ever), menopausal status and age at menopause (premenopausal, $<45,45$ to 49,50 to $54, \geq 55$ years), female hormone use $(0,<5, \geq 5$ years of use), body mass index (weight in kilograms divided by height in meters squared; <18.5, 18.5 to $24.9,25.0$ to $29.9,30.0$ to $\left.34.9, \geq 35.0 \mathrm{~kg} / \mathrm{m}^{2}\right)$, educational attainment $(<12,12,13$ to $15,16,>16$ years), alcohol consumption $(<1,1$ to $6, \geq 7$ drinks per week), smoking status $(0,<10,10$ to $19, \geq 20$ pack-years), and geographic region (New Jersey, other Northeast, South, Midwest, West). We used the missing indicator method to handle missing data. For menopausal status, $8.8 \%$ of women had missing data; for each of the other covariates, fewer than $2 \%$ had missing data. To test for trend across categories of $\mathrm{OC}$ duration or $\mathrm{OC}$ recency, the ordinal variable was treated as a continuous variable in the regression model. Trend tests were carried out among OC users only. To examine potential differences by subtype, we carried out case-case analyses, in which ORs were computed for the relation of OC use to ERrelative to ER+ breast cancer. Effect modification was explored through stratification by age, menopausal status, body mass index, and parity. Interaction on the multiplicative scale was tested by the likelihood ratio test, comparing models with and without multiplicative interaction terms. Analyses were performed using SAS 9.2 statistical software (SAS Institute Inc., Cary, NC, USA).
In addition to the main analyses, which were carried out in pooled data, study-specific ORs were calculated and combined in a random-effects meta-analysis. The Cochran's Q statistic was used to test for heterogeneity [37]. Meta-analyses were performed using Stata/SE 11.2 statistical software (StataCorp LP, College Station, TX, USA).

\section{Results}

Characteristics of cases and controls are presented in Table 1 . Among the 2,891 cases, 1,043 (36\%) had tumors that were classified as ER- and 1,848 (64\%) were classified as ER+ (Table 1). In addition, 494 of the ER- cases were TN breast cancer. The mean age at diagnosis was 52.7 , with $11.2 \%$ of cases diagnosed before age 40 and $27.3 \%$ diagnosed at age 60 or older. OC use was similar across the three participating studies.

Table 2 presents analyses of OC use in relation to ER+ and ER- breast cancer. Ever OC use was positively associated with both $\mathrm{ER}+(\mathrm{OR}=1.15,95 \% \mathrm{CI}=1.02$ to 1.28$)$ and $\mathrm{ER}-(\mathrm{OR}=1.24,95 \% \mathrm{CI}=1.07$ to 1.43$)$ breast cancer. There was a significant dose-response association with recency of OC use for both ER+ and ER- breast cancer ( $P$ trend $<0.01$ and $P$ trend $=0.05$, respectively). The strongest associations were for $\mathrm{OC}$ use within the previous 5 years $(\mathrm{OR}=1.46,95 \% \mathrm{CI}=1.18$ to 1.81 for $\mathrm{ER}+$ breast cancer and $\mathrm{OR}=1.57,95 \% \mathrm{CI}=1.22$ to 2.03 for ER- breast cancer). For ER+ breast cancer, the ORs were elevated through 15 to 19 years since last use and the estimate for 15 to 19 years was statistically significant $(\mathrm{OR}=1.29,95 \% \mathrm{CI}=1.04$ to 1.58$)$. For $\mathrm{ER}-$ breast cancer, the pattern was less consistent; the OR declined to $1.07(95 \% \mathrm{CI}=, 0.83$ to 1.37$)$ at 20 to 24 years since last use, but there was a statistically significant elevation at 25 to 29 years since last use $(\mathrm{OR}=1.41,95 \% \mathrm{CI}=1.09$ to 1.81$)$. Risk of ER- cancer increased with increasing duration of OC use, with ORs of 1.43 ( $95 \% \mathrm{CI}=1.13$ to 1.80 ) and 1.54 ( $95 \% \mathrm{CI}=1.15$ to 2.06 ) for 10 to 14 and $\geq 15$ years duration, respectively. For ER+ breast cancer, the OR for 10 to 14 years duration was elevated $(1.35,95 \% \mathrm{CI}=1.12$ to 1.61) but the estimate for $\geq 15$ years was approximately 1.00. Among recent users, risk increased with increasing duration of $\mathrm{OC}$ use for both ER+ and ER- cancer. The OR for $\geq 10$ years of use that continued into the 5 years before diagnosis or index date was $1.65(95 \% \mathrm{CI}=1.27$ to 2.15) for $E R+$ cancer and $1.73(95 \% \mathrm{CI}=1.26$ to 2.37 ) for ER- cancer. The corresponding estimates for $\geq 10$ years of use that ended at least 20 years previously was 0.88 (95\% $\mathrm{CI}=0.65$ to 1.19$)$ for $\mathrm{ER}+$ cancer and $1.50(95 \% \mathrm{CI}=1.03$ to 2.17) for ER- cancer.

In a case-case analysis (data not shown), ever use of OCs $(\mathrm{OR}=1.09,95 \% \mathrm{CI}=0.92$ to 1.29$)$ and $\mathrm{OC}$ use within the previous 5 years $(\mathrm{OR}=1.08,95 \% \mathrm{CI}=0.79$ to 1.46) were not associated with ER- breast cancer, 
Table 2 Oral contraceptive use in relation to ER+ and ER- breast cancer ${ }^{\mathrm{a}}$

\begin{tabular}{|c|c|c|c|c|c|c|c|}
\hline & \multirow[b]{2}{*}{ Controls $(n)$} & \multicolumn{3}{|l|}{ ER+ } & \multicolumn{3}{|l|}{ ER- } \\
\hline & & Cases $(n)$ & OR & $(95 \% \mathrm{Cl})$ & Cases $(n)$ & OR & $(95 \% \mathrm{Cl})$ \\
\hline Never users & 4,632 & 862 & 1.00 & Reference & 429 & 1.00 & Reference \\
\hline Ever users & 5,415 & 990 & 1.15 & (1.02 to 1.28$)$ & 615 & 1.24 & (1.07 to 1.43$)$ \\
\hline \multicolumn{8}{|l|}{ OC recency } \\
\hline$<5$ years ago & 1,075 & 183 & 1.46 & (1.18 to 1.81$)$ & 131 & 1.57 & (1.22 to 2.03 ) \\
\hline 5 to 9 years ago & 544 & 84 & 1.16 & (0.89 to 1.52 ) & 64 & 1.33 & (0.97 to 1.82$)$ \\
\hline 10 to 14 years ago & 595 & 105 & 1.25 & (0.98 to 1.60$)$ & 64 & 1.12 & (0.82 to 1.52$)$ \\
\hline 15 to 19 years ago & 757 & 153 & 1.28 & (1.04 to 1.58$)$ & 92 & 1.14 & (0.88 to 1.48 ) \\
\hline 20 to 24 years ago & 859 & 148 & 1.01 & (0.82 to 1.24$)$ & 97 & 1.07 & (0.83 to 1.37 ) \\
\hline 25 to 29 years ago & 781 & 123 & 0.93 & (0.75 to 1.15 ) & 91 & 1.41 & (1.09 to 1.81$)$ \\
\hline$\geq 30$ years ago & 795 & 185 & 1.14 & (0.94 to 1.38$)$ & 71 & 1.14 & (0.85 to 1.51$)$ \\
\hline$P$ trend & & & $<0.01$ & & & 0.05 & \\
\hline \multicolumn{8}{|l|}{ OC duration } \\
\hline$<5$ years & 2,315 & 367 & 1.03 & (0.89 to 1.19 ) & 260 & 1.21 & (1.01 to 1.44$)$ \\
\hline 5 to 9 years & 1,629 & 321 & 1.25 & (1.07 to 1.46$)$ & 160 & 1.07 & (0.87 to 1.32 ) \\
\hline 10 to 14 years & 1,010 & 209 & 1.35 & (1.12 to 1.61$)$ & 121 & 1.43 & (1.13 to 1.80$)$ \\
\hline$\geq 15$ years & 458 & 89 & 0.98 & (0.76 to 1.27 ) & 73 & 1.54 & (1.15 to 2.06$)$ \\
\hline$P$ trend & & & 0.13 & & & 0.05 & \\
\hline
\end{tabular}

Joint OC exposure (recency and duration)

\begin{tabular}{|c|c|c|}
\hline Since last use & Duration & \\
\hline \multirow[t]{3}{*}{$<5$ years } & $<5$ years & 329 \\
\hline & 5 to 9 years & 289 \\
\hline & $\geq 10$ years & 457 \\
\hline \multirow[t]{3}{*}{5 to 9 years } & $<5$ years & 172 \\
\hline & 5 to 9 years & 140 \\
\hline & $\geq 10$ years & 232 \\
\hline \multirow[t]{3}{*}{10 to 19 years } & $<5$ years & 466 \\
\hline & 5 to 9 years & 451 \\
\hline & $\geq 10$ years & 435 \\
\hline \multirow[t]{3}{*}{$\geq 20$ years } & $<5$ years & 1,344 \\
\hline & 5 to 9 years & 748 \\
\hline & $\geq 10$ years & 340 \\
\hline
\end{tabular}

\begin{tabular}{llllll}
39 & 1.13 & $(0.78$ to 1.62$)$ & 30 & 1.20 & (0.78 to 1.83$)$ \\
45 & 1.60 & $(1.12$ to 2.28$)$ & 33 & 1.67 & (1.10 to 2.53) \\
99 & 1.65 & $(1.27$ to 2.15$)$ & 68 & 1.73 & (1.26 to 2.37) \\
22 & 1.21 & $(0.75$ to 1.94$)$ & 16 & 1.26 & (0.72 to 2.21) \\
30 & 1.62 & $(1.05$ to 2.52$)$ & 13 & 0.94 & (0.51 to 1.74$)$ \\
32 & 0.92 & $(0.62$ to 1.38$)$ & 35 & 1.59 & (1.06 to 2.38) \\
66 & 1.09 & $(0.82$ to 1.47$)$ & 58 & 1.21 & (0.87 to 1.67$)$ \\
87 & 1.33 & $(1.02$ to 1.73$)$ & 46 & 0.94 & (0.66 to 1.33$)$ \\
105 & 1.41 & $(1.11$ to 1.81$)$ & 52 & 1.24 & (0.90 to 1.72$)$ \\
238 & 1.02 & $(0.86$ to 1.20$)$ & 155 & 1.23 & $(1.00$ to 1.51$)$ \\
157 & 1.13 & $(0.92$ to 1.38$)$ & 65 & 1.00 & (0.75 to 1.33$)$ \\
61 & 0.88 & $(0.65$ to 1.19$)$ & 39 & 1.50 & (1.03 to 2.17$)$ \\
\hline
\end{tabular}

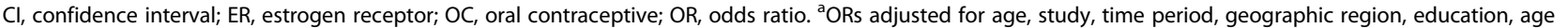
at menarche, parity, age at first birth, lactation, first-degree family history of breast cancer, menopausal status and age at menopause, duration of female hormone use, body mass index, alcohol consumption, and pack-years of cigarette smoking. $P$ trend does not include never users.

relative to ER+ breast cancer. Increased risk of ER- breast cancer was associated with long duration ( $\geq 15$ years) of OC use relative to ER+ cancer: the OR was 1.51 (95\% $\mathrm{CI}=1.07$ to 2.15 ).

In an analysis stratified by invasive and in situ breast cancer (data not shown), results for invasive cancer (1,150 ER+ and $629 \mathrm{ER}$ - cases) were similar to the overall findings: the ORs for invasive ER+ cancer were 1.14 $(95 \% \mathrm{CI}=1.00$ to 1.31$)$ for ever use, $1.41(95 \% \mathrm{CI}=1.10$ to 1.81) for use within the previous 5 years, and 0.95 (0.69 to 1.30) for duration of 15 years or more; the corresponding estimates for invasive ER- cancer were $1.36(95 \% \mathrm{CI}=1.14$ to 1.62$), 1.62(95 \% \mathrm{CI}=1.20$ to 2.20$)$ and 1.59 (1.11 to 2.29), respectively. For in situ cancer, based on $255 \mathrm{ER}+$ cases, risk of ER+ breast cancer was significantly elevated for recent $\mathrm{OC}$ use $(\mathrm{OR}=1.66,95 \%$ $\mathrm{CI}=1.02$ to 2.68 ), but was not associated with long duration of $\mathrm{OC}$ use $(\mathrm{OR}=0.95,95 \% \mathrm{CI}=0.51$ to 1.75$)$. There were too few ER- in situ cases $(n=43)$ for an informative analysis.

The relation of OC use to risk of TN breast cancer is presented in Table 3. The OR for recent use of OCs 
Table 3 Oral contraceptive use in relation to triple-negative breast cancer ${ }^{a}$

\begin{tabular}{|c|c|c|c|c|}
\hline & Controls $(n)$ & Cases $(n)$ & OR & $(95 \% \mathrm{Cl})$ \\
\hline Never users & 4,632 & 213 & 1.00 & Reference \\
\hline Ever users & 5,415 & 282 & 1.14 & (0.93 to 1.40 ) \\
\hline \multicolumn{5}{|l|}{ OC recency } \\
\hline$<5$ years ago & 1,075 & 66 & 1.78 & (1.25 to 2.53$)$ \\
\hline 5 to 9 years ago & 544 & 33 & 1.37 & (0.88 to 2.12 ) \\
\hline 10 to 14 years ago & 595 & 37 & 0.99 & (0.63 to 1.56$)$ \\
\hline 15 to 19 years ago & 757 & 47 & 1.19 & (0.83 to 1.72$)$ \\
\hline 20 to 24 years ago & 859 & 40 & 0.85 & (0.89 to 1.24$)$ \\
\hline 25 to 29 years ago & 781 & 40 & 1.26 & (0.87 to 1.81$)$ \\
\hline$\geq 30$ years ago & 795 & 30 & 0.91 & (0.59 to 1.38$)$ \\
\hline$P$ trend & & & 0.05 & \\
\hline \multicolumn{5}{|l|}{ OC duration } \\
\hline$<5$ years & 2,315 & 117 & 1.08 & (0.84 to 1.39$)$ \\
\hline 5 to 9 years & 1,629 & 73 & 0.99 & (0.74 to 1.34$)$ \\
\hline 10 to 14 years & 1,010 & 51 & 1.26 & (0.90 to 1.77 ) \\
\hline$\geq 15$ years & 458 & 40 & 1.62 & (1.11 to 2.38$)$ \\
\hline$P$ trend & & & 0.05 & \\
\hline
\end{tabular}

\section{Joint OC exposure}

\begin{tabular}{|c|c|c|c|c|c|}
\hline Since last use & Duration & & & & \\
\hline \multirow[t]{3}{*}{$<5$ years } & $<5$ years & 329 & 14 & 1.31 & (0.72 to 2.40 ) \\
\hline & 5 to 9 years & 289 & 21 & 2.70 & (1.58 to 4.61 ) \\
\hline & $\geq 10$ years & 457 & 30 & 1.66 & (1.06 to 2.60$)$ \\
\hline \multirow[t]{3}{*}{5 to 9 years } & $<5$ years & 172 & 5 & 0.89 & (0.35 to 2.30$)$ \\
\hline & 5 to 9 years & 140 & 7 & 1.08 & (0.47 to 2.48 ) \\
\hline & $\geq 10$ years & 232 & 19 & 1.79 & (1.04 to 3.07 ) \\
\hline \multirow[t]{3}{*}{10 to 19 years } & $<5$ years & 466 & 26 & 1.12 & (0.70 to 1.79 ) \\
\hline & 5 to 9 years & 451 & 21 & 0.87 & (0.53 to 1.45 ) \\
\hline & $\geq 10$ years & 435 & 27 & 1.36 & (0.87 to 2.11 ) \\
\hline \multirow[t]{3}{*}{$\geq 20$ years } & $<5$ years & 1,344 & 72 & 1.11 & (0.83 to 1.49 ) \\
\hline & 5 to 9 years & 748 & 22 & 0.67 & (0.42 to 1.06 ) \\
\hline & $\geq 10$ years & 340 & 15 & 1.14 & (0.65 to 2.00$)$ \\
\hline
\end{tabular}

$\mathrm{Cl}$, confidence interval; $\mathrm{OC}$, oral contraceptive; OR, odds ratio. ${ }^{\mathrm{a}} \mathrm{ORs}$ adjusted for age, study, time period, geographic region, education, age at menarche, parity, age at first birth, lactation, first-degree family history of breast cancer, menopausal status and age at menopause, duration of female hormone use, body mass index, alcohol consumption, and pack-years of cigarette smoking. $P$ trend does not include never users.

relative to never use was $1.78(95 \% \mathrm{CI}=1.25$ to 2.53$)$ and risk declined as the interval since last use increased ( $P$ trend $=0.05)$. Risk increased with increasing duration of OC use, with an OR of $1.62(95 \% \mathrm{CI}=1.11$ to 2.38$)$ for $\geq 15$ years of use $(P$ trend $=0.05)$. Analyses of a joint variable for duration and recency of use indicated that the increased risk associated with at least 10 years of OC use was statistically significant both for use less than 5 years ago $(\mathrm{OR}=1.66,95 \% \mathrm{CI}=1.06$ to 2.00$)$ and use 5 to 9 years ago $(\mathrm{OR}=1.79,95 \% \mathrm{CI}=1.04$ to 3.07$)$.

In analyses stratified by age $(<40$ years, 40 to 49 years, $\geq 50$ years), recent and long-duration $\mathrm{OC}$ use were associated with increased risk of breast cancer in every age group (Table 4). The interaction was not statistically significant for $\mathrm{OC}$ recency or duration ( $P$ interaction $=0.75$ and $P$ interaction $=0.77$, respectively).

In analyses stratified by menopausal status (Table 5), ORs were higher in premenopausal women, but there was not a statistically significant interaction $(P$ interaction $=$ 0.16 for recency, $P$ interaction $=0.06$ for duration). Breast cancer risk was elevated for recent $\mathrm{OC}$ use in both nulliparous and parous women (Table 5): among nulliparous women the OR for OC use within the previous 5 years was 1.37 ( $95 \% \mathrm{CI}=0.98$ to 1.92 ), and the corresponding 
Table 4 Oral contraceptive use in relation to breast cancer risk, stratified by age

\begin{tabular}{|c|c|c|c|c|c|c|c|c|c|c|c|c|}
\hline & \multicolumn{4}{|l|}{ Age $<40$} & \multicolumn{4}{|l|}{ Age 40 to 49} & \multicolumn{4}{|l|}{ Age $\geq 50$} \\
\hline & Controls $(n)$ & Cases $(n)$ & OR & $(95 \% \mathrm{Cl})$ & Controls $(n)$ & Cases $(n)$ & OR & $(95 \% \mathrm{Cl})$ & Controls $(n)$ & Cases $(n)$ & OR & $(95 \% \mathrm{Cl})$ \\
\hline Never users & 351 & 85 & 1.00 & Reference & 1,022 & 272 & 1.00 & Reference & 3,259 & 934 & 1.00 & Reference \\
\hline Ever users & 796 & 239 & 1.33 & (0.97 to 1.81 ) & 2,057 & 584 & 1.18 & (0.98 to 1.42 ) & 2,562 & 782 & 1.15 & (1.01 to 1.30 ) \\
\hline \multicolumn{13}{|l|}{ OC recency } \\
\hline$<5$ years ago & 482 & 130 & 1.55 & (1.09 to 2.19 ) & 482 & 149 & 1.60 & (1.23 to 2.07 ) & 111 & 35 & 1.50 & (0.99 to 2.28) \\
\hline 5 to 9 years ago & 185 & 53 & 1.20 & (0.77 to 1.86 ) & 292 & 74 & 1.18 & (0.86 to 1.63 ) & 94 & 21 & 0.95 & (0.57 to 1.58$)$ \\
\hline$\geq 10$ years ago & 154 & 56 & 1.04 & (0.67 to 1.61$)$ & 1,282 & 361 & 1.07 & (0.88 to 1.31 ) & 2,351 & 716 & 1.14 & (1.00 to 1.29 ) \\
\hline$P$ trend & & & 0.02 & & & & $<0.01$ & & & & 0.45 & \\
\hline \multicolumn{13}{|l|}{ OC duration } \\
\hline$<5$ years & 342 & 84 & 1.18 & (0.81 to 1.70 ) & 835 & 225 & 1.12 & (0.90 to 1.40 ) & 1,138 & 318 & 1.08 & (0.92 to 1.27 ) \\
\hline 5 to 9 years & 239 & 79 & 1.40 & (0.95 to 2.06 ) & 629 & 160 & 1.06 & (0.83 to 1.35 ) & 761 & 242 & 1.20 & (1.00 to 1.44$)$ \\
\hline$\geq 10$ years & 215 & 76 & 1.48 & (0.99 to 2.20 ) & 593 & 199 & 1.39 & (1.10 to 1.76$)$ & 660 & 217 & 1.20 & (0.99 to 1.45 ) \\
\hline$P$ trend & & & 0.17 & & & & 0.11 & & & & 0.26 & \\
\hline
\end{tabular}

$\mathrm{Cl}$, confidence interval; $\mathrm{OC}$, oral contraceptive; $\mathrm{OR}$, odds ratio. ${ }^{2} \mathrm{ORs}$ adjusted for age, study, time period, geographic region, education, age at menarche, parity, age at first birth, lactation, first-degree family history of breast cancer, menopausal status and age at menopause, duration of female hormone use, body mass index, alcohol consumption, and pack-years of cigarette smoking. $P$ trend does not include never users. 
Table 5 Oral contraceptive use in relation to breast cancer risk, stratified by menopausal status and parity ${ }^{a}$

\begin{tabular}{|c|c|c|c|c|c|c|c|c|}
\hline & Controls $(n)$ & Cases $(n)$ & OR & $(95 \% \mathrm{Cl})$ & Controls $(n)$ & Cases $(n)$ & OR & $(95 \% \mathrm{Cl})$ \\
\hline & \multicolumn{4}{|c|}{ Premenopausal women } & \multicolumn{4}{|c|}{ Postmenopausal women } \\
\hline Never users & 1,371 & 363 & 1.00 & Reference & 2,903 & 854 & 1.00 & Reference \\
\hline Ever users & 2,667 & 767 & 1.24 & (1.05 to 1.45$)$ & 2,184 & 703 & 1.16 & (1.01 to 1.33 ) \\
\hline \multicolumn{9}{|l|}{ OC recency } \\
\hline$<5$ years ago & 937 & 273 & 1.54 & (1.25 to 1.90$)$ & 90 & 19 & 1.02 & (0.59 to 1.76$)$ \\
\hline 5 to 9 years ago & 404 & 113 & 1.31 & (1.01 to 1.72$)$ & 99 & 21 & 0.85 & (0.50 to 1.44$)$ \\
\hline$\geq 10$ years ago & 1,324 & 380 & 1.08 & (0.90 to 1.30$)$ & 1,989 & 654 & 1.17 & (1.02 to 1.34$)$ \\
\hline$P$ trend & & & $<0.01$ & & & & 0.39 & \\
\hline \multicolumn{9}{|l|}{ OC duration } \\
\hline$<5$ years & 1,066 & 276 & 1.11 & (0.91 to 1.35$)$ & 992 & 301 & 1.14 & (0.96 to 1.36$)$ \\
\hline 5 to 9 years & 818 & 217 & 1.14 & (0.92 to 1.41$)$ & 648 & 222 & 1.24 & (1.02 to 1.50$)$ \\
\hline$\geq 10$ years & 782 & 274 & 1.53 & (1.25 to 1.88$)$ & 542 & 175 & 1.09 & (0.88 to 1.34$)$ \\
\hline \multirow[t]{2}{*}{$P$ trend } & & & $<0.01$ & & & & 0.83 & \\
\hline & \multicolumn{4}{|c|}{ Nulliparous women } & \multicolumn{4}{|c|}{ Parous women } \\
\hline Never users & 917 & 244 & 1.00 & Reference & 3,706 & 1,046 & 1.00 & Reference \\
\hline Ever users & 1,230 & 267 & 1.09 & (0.87 to 1.38 ) & 4,183 & 1,338 & 1.21 & (1.08 to 1.35$)$ \\
\hline \multicolumn{9}{|l|}{ OC recency } \\
\hline$<5$ years ago & 406 & 93 & 1.37 & (0.98 to 1.92$)$ & 669 & 211 & 1.55 & (1.26 to 1.90$)$ \\
\hline 5 to 9 years ago & 160 & 22 & 0.77 & (0.46 to 1.29$)$ & 383 & 126 & 1.39 & (1.08 to 1.77 ) \\
\hline$\geq 10$ years ago & 663 & 151 & 1.05 & (0.81 to 1.36$)$ & 3,123 & 982 & 1.15 & (1.03 to 1.29$)$ \\
\hline$P$ trend & & & 0.16 & & & & $<0.01$ & \\
\hline \multicolumn{9}{|l|}{ OC duration } \\
\hline$<5$ years & 438 & 89 & 1.06 & (0.79 to 1.44$)$ & 1,875 & 538 & 1.11 & (0.97 to 1.27 ) \\
\hline 5 to 9 years & 361 & 76 & 1.08 & (0.78 to 1.50$)$ & 1,268 & 405 & 1.22 & (1.05 to 1.42 ) \\
\hline$\geq 10$ years & 431 & 102 & 1.13 & (0.84 to 1.52 ) & 1,037 & 390 & 1.37 & (1.17 to 1.60$)$ \\
\hline$P$ trend & & & 0.61 & & & & 0.01 & \\
\hline
\end{tabular}

$\mathrm{Cl}$, confidence interval; OC, oral contraceptive; OR, odds ratio. ${ }^{\mathrm{a}} \mathrm{ORs}$ adjusted for age, study, time period, geographic region, education, age at menarche, parity, age at first birth, lactation, first-degree family history of breast cancer, menopausal status and age at menopause, duration of female hormone use, body mass index, alcohol consumption, and pack-years of cigarette smoking, where appropriate. $P$ trend does not include never users. Women who were missing menopausal status $(n=1,218)$ were excluded from the analysis that stratified on this variable. Women who were missing parity $(n=13)$ were excluded from the analysis that stratified on this variable.

OR for parous women was 1.55 (95\% CI $=1.26$ to 1.90$)$ $(P$ interaction $=0.08)$. Long duration of OC use was associated with breast cancer among parous women, but not among nulliparous women (Table 5). The interaction was not significant $(P=0.42)$.

Recent and long-duration OC use were associated with larger increases in breast cancer risk among women who were overweight or obese than among women with body mass index $<25 \mathrm{~kg} / \mathrm{m}^{2}$ (Table 6). The interaction was significant for recent $\mathrm{OC}$ use $(P$ interaction $=0.04)$, but not for duration of OC use $(P$ interaction $=0.16)$.

Figure 1 presents study-specific estimates and ORs for recent (within previous 5 years) and long-term ( $\geq 10$ years) OC use in relation to ER+ and ER- breast cancer computed from a meta-analysis with a randomeffects model. The $P$ value for heterogeneity was 0.57 or greater for all comparisons, indicating no statistically significant heterogeneity.

\section{Discussion}

Both recent $\mathrm{OC}$ use and long duration of $\mathrm{OC}$ use were associated with increased risk of breast cancer in this study of African American women. The positive associations were observed for ER+, ER-, and TN breast cancer. ORs were highest for TN breast cancer: women who had used OCs in the past 5 years were estimated to have a 78\% increased risk of TN breast cancer and those who had used OCs for at least 15 years had a $62 \%$ increase.

While some studies have found no association of recent $\mathrm{OC}$ use with overall breast cancer risk [2,3,5,38,39], many others have reported that recent $\mathrm{OC}$ users 
Table 6 Oral contraceptive use in relation to breast cancer risk, stratified by body mass index ${ }^{a}$

\begin{tabular}{|c|c|c|c|c|c|c|c|c|c|c|c|c|}
\hline & \multicolumn{4}{|c|}{$\mathrm{BMI}<25.0 \mathrm{~kg} / \mathrm{m}^{2}$} & \multicolumn{4}{|c|}{ BMI 25.0 to $29.9 \mathrm{~kg} / \mathrm{m}^{2}$} & \multicolumn{4}{|c|}{$\mathrm{BMI} \geq 30.0 \mathrm{~kg} / \mathrm{m}^{2}$} \\
\hline & Controls $(n)$ & Cases $(n)$ & OR & $(95 \% \mathrm{Cl})$ & Controls $(n)$ & Cases $(n)$ & OR & $(95 \% \mathrm{Cl})$ & Controls $(n)$ & Cases $(n)$ & OR & $(95 \% \mathrm{Cl})$ \\
\hline Never users & 931 & 231 & 1.00 & Reference & 1,503 & 387 & 1.00 & Reference & 2,096 & 637 & 1.00 & Reference \\
\hline Ever users & 1,371 & 350 & 1.09 & (0.88 to 1.35$)$ & 1,746 & 521 & 1.13 & (0.95 to 1.35$)$ & 2,211 & 707 & 1.26 & (1.09 to 1.45$)$ \\
\hline \multicolumn{13}{|l|}{ OC recency } \\
\hline$<5$ years ago & 361 & 87 & 1.22 & (0.87 to 1.71$)$ & 320 & 111 & 1.58 & (1.16 to 2.14$)$ & 377 & 112 & 1.57 & (1.19 to 2.08$)$ \\
\hline 5 to 9 years ago & 156 & 32 & 0.87 & (0.55 to 1.38$)$ & 175 & 46 & 1.06 & (0.71 to 1.58$)$ & 204 & 69 & 1.71 & (1.23 to 2.37$)$ \\
\hline$\geq 10$ years ago & 851 & 230 & 1.09 & (0.87 to 1.38$)$ & 1,248 & 363 & 1.09 & (0.90 to 1.31$)$ & 1,627 & 518 & 1.17 & (1.01 to 1.36$)$ \\
\hline$P$ trend & & & 0.17 & & & & 0.05 & & & & 0.04 & \\
\hline \multicolumn{13}{|l|}{ OC duration } \\
\hline$<5$ years & 566 & 135 & 1.05 & (0.80 to 1.37 ) & 726 & 198 & 1.12 & (0.90 to 1.39 ) & 986 & 278 & 1.09 & (0.91 to 1.30$)$ \\
\hline 5 to 9 years & 408 & 109 & 1.11 & (0.83 to 1.49 ) & 544 & 152 & 1.04 & (0.82 to 1.33 ) & 651 & 213 & 1.34 & (1.09 to 1.64$)$ \\
\hline$\geq 10$ years & 397 & 105 & 1.11 & (0.83 to 1.50 ) & 476 & 171 & 1.27 & (1.00 to 1.61$)$ & 571 & 212 & 1.48 & (1.20 to 1.82$)$ \\
\hline$P$ trend & & & 0.67 & & & & 0.48 & & & & $<0.01$ & \\
\hline
\end{tabular}

$\mathrm{BMI}$, body mass index; $\mathrm{Cl}$, confidence interval; $\mathrm{OC}$, oral contraceptive; $\mathrm{OR}$, odds ratio. ${ }^{\mathrm{O} O R s}$ adjusted for age, study, time period, geographic region, education, age at menarche, parity, age at first birth, lactation,

first-degree family history of breast cancer, menopausal status and age at menopause, duration of female hormone use, body mass index, alcohol consumption, and pack-years of cigarette smoking. $P$ trend does not include never users. 


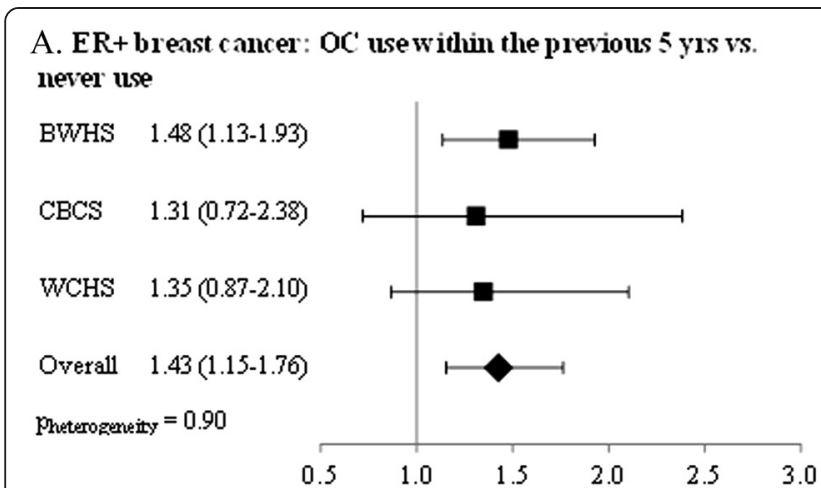

C. ER+breast cancer: $\geq 10$ yrs of $O C$ use vs. never use

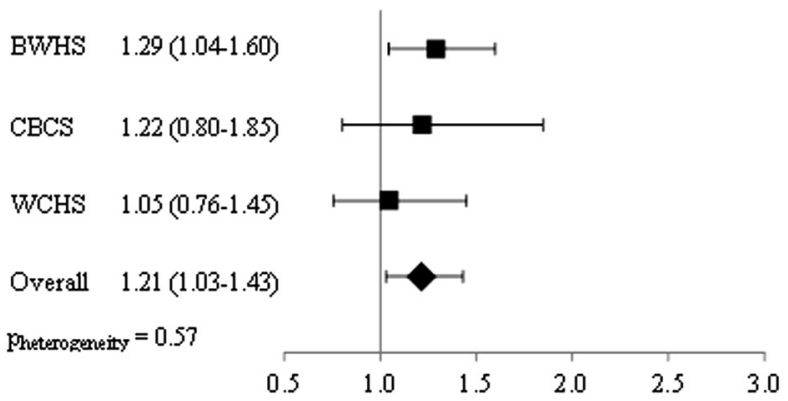

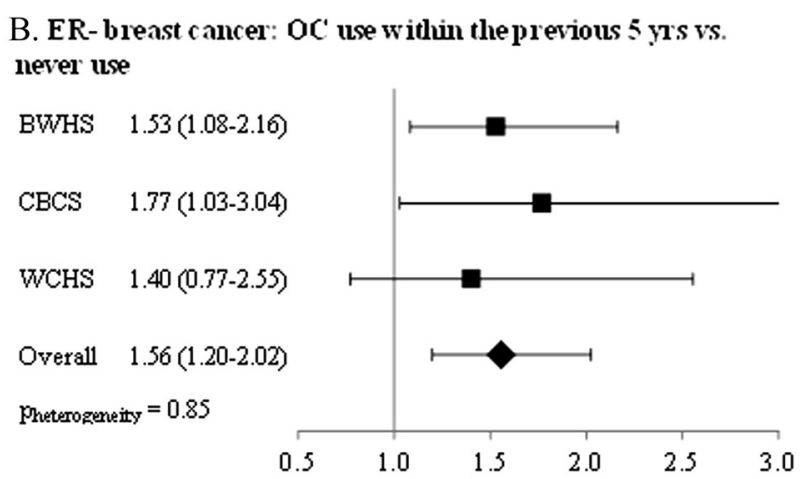

D. ER-breast cancer: $\geq 10$ yns of $O C$ use vs. never use

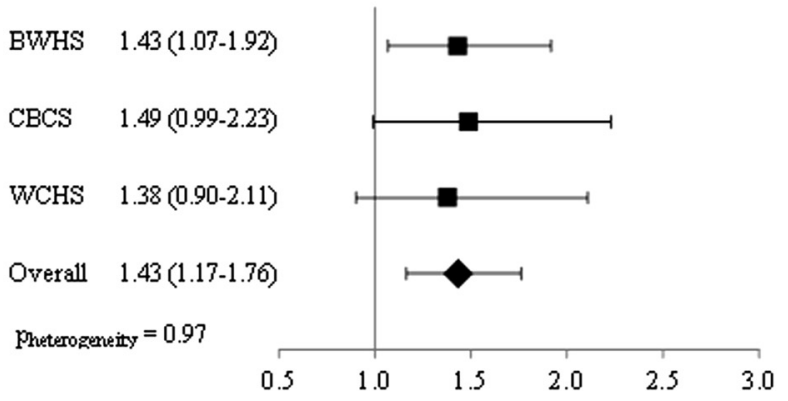

Figure 1 Results from meta-analysis of oral contraceptive recency and duration in relation to breast cancer subtype. Odds ratios and 95\% confidence intervals from the full model by study and from a random-effects meta-analysis for oral contraceptive (OC) recency in relation to ER+ (A) and ER- (B) breast cancer and OC duration in relation to ER+ (C) and ER- (D) breast cancer. BWHS, Black Women's Health Study; CBCS, Carolina Breast Cancer Study; ER, estrogen receptor; WCHS, Women's Circle of Health Study.

experience an increase in risk, which has varied from $24 \%$ to $60 \%[1,6,9,11,12,40]$. The present findings are similar in magnitude to the previous positive associations. A collaborative analysis of 54 studies concluded that the increased risk of breast cancer associated with OC use disappears by 10 years after last use [1]. In a large case-control study that included African American women, no association was observed for long intervals ( $\geq 20$ years) since last OC use [2,3]. However, in the present study of African American women, an increased risk was present up to 15 to 19 years after last use for $\mathrm{ER}+$ cancer and after an even longer interval for ERcancer. Results for duration of use are less consistent in the literature, with some studies reporting no association with long duration [2,3,25,39,41-43] while others observed a positive association [4-13]. In the present study, long duration use appeared to be more strongly associated with ER- cancer than with ER+ cancer.

There are few previous studies of OC use with molecular subtype of breast cancer. Five studies found associations of OC use with both ER+ and ER- breast cancer $[4,8-10,12]$. One study found an association for only ER+ breast cancer [24] and two found an association for only
ER- breast cancer $[23,44]$, while two other studies found no association for either subtype $[45,46]$. Of the studies that could evaluate $\mathrm{TN}$ or basal-like breast cancer, three found a positive association $[10,23,26,47]$ while two others observed no association $[2,25]$.

Combination OCs contain estrogens and progestins and have been found to increase circulating levels of estradiol $[48,49]$. A potential mechanism for increased risk of breast cancer with recent OC use is through estrogen-induced or progesterone-induced proliferation of breast cancer cells [50,51], which could cause progression of breast cancer. This mechanism may not be applicable for ER- breast cancer. Estrogens may also promote angiogenesis and stromal cell recruitment [52], which would be relevant for both ER+ and ER- breast cancer. OCs may also cause epigenetic changes, such as a decrease in DNA methylation [53]. DNA hypomethylation may be associated with tumor progression and metastasis [54] and represents another potential mechanism for the relation of $\mathrm{OC}$ use to breast cancer risk. It has been suggested that tumors regress after cessation of use of menopausal hormone supplements [55,56]. The tumors associated with menopausal hormone use are ER+. 
Whether tumor regression occurs after cessation of OC use is unknown, but this mechanism might not explain results for ER- breast cancer.

Few studies have examined potential effect modification of the relation of $\mathrm{OC}$ use to breast cancer risk by age $[9,23,57]$. Of these, some studies have observed a stronger association with risk among younger women than among older women, but this difference has generally not been statistically significant $[4,26,58,59]$. In a report from the BWHS, age did not significantly modify the association of OC use with breast cancer subtype [9]. In a Washington state case-control study, ORs for OC use were higher among women under age 40, but there was not a significant interaction by age [23]. In a multisite case-control study, ORs for OC use were significantly higher among women under age 35 and age 35 to 44 years, compared with women age 45 years and older [57]. In the present study, ORs were somewhat higher in the youngest age group, but there was not a significant interaction. ORs were also higher among premenopausal women than among postmenopausal women, but, again, the interaction was not statistically significant and there were few recent users among the postmenopausal women. Previous studies have observed associations of OC use with breast cancer risk in both premenopausal and postmenopausal women $[8,45]$.

Differences in risk of breast cancer by age or menopausal status could reflect changes in $\mathrm{OC}$ formulations. The estrogen and progestin composition of OCs has varied, with declining doses of hormones and new types of progestin introduced over time $[40,60,61]$. There is no clear evidence that some formulations carry higher risk than others [5,62-64]. We were not able to evaluate formulation, as we did not have detailed information on OC type used. Thus, we cannot rule out the possibility that associations vary according to $\mathrm{OC}$ formulation. However, while younger women are more likely to use newer OC formulations, our findings did not vary significantly by strata of age or birth cohort in the present study. Moreover, estimates were similar across the studies, which were conducted in different time frames ranging from 1993 to present.

The associations of $\mathrm{OC}$ use with breast cancer risk in the present study were stronger among overweight and obese women. No previous studies have assessed whether an association of breast cancer risk with recent or long duration of $\mathrm{OC}$ use is modified by body mass index. This finding is particularly important given the high prevalence of obesity in African American women [65]. Obesity may alter the pharmacokinetic parameters of OCs, which could prolong exposure to estrogen in obese women due to an increase in the half-life of circulating estradiol, an increase in the rate of $\mathrm{OC}$ absorption, or an increase in bioavailability of the chemical compounds in the OCs [66-68].
The present analysis is the largest yet conducted of $\mathrm{OC}$ use in relation to specific subtypes of breast cancer among African American women. It allowed for informative assessment of associations within subtype overall and within some strata of interest. However, statistical power in some subanalyses was limited. Numerous important risk factors for breast cancer were controlled in the analyses. While the studies that contributed to the present analyses differed in study design and in population characteristics, a meta-analysis found no significant heterogeneity in the results. In addition, results on other risk factors, including parity and body size, have been similar across the individual studies [8,21,69-72]. Thus, the results are likely to be generalizable to other African American women. A limitation was that the classification by molecular subtype was based on the particular methods used in each pathology laboratory in the large number of hospitals from which the cases were derived. However, it is unlikely that misclassification will have been related to the OC use of cases. We did not have data to validate self-reported $\mathrm{OC}$ use, but validation studies have shown that $\mathrm{OC}$ use is generally well reported [5,73,74]. We did not have detailed information on OC type used, and therefore cannot rule out variations in associations by $\mathrm{OC}$ formulation.

\section{Conclusions}

In sum, our findings suggest that recent $\mathrm{OC}$ use, particularly of long duration, is associated with increased risk of ER+, ER-, and TN breast cancer in African American women, with possibly a stronger relation with $\mathrm{TN}$ breast cancer. Increases in risk associated with OC use were apparent for up to 15 years or more after cessation of use. The association with $\mathrm{OC}$ use was most pronounced among overweight and obese women. Research is needed to investigate the mechanisms by which obesity may further increase the breast cancer risk associated with $\mathrm{OC}$ use.

\section{Abbreviations \\ AMBER: African American Breast Cancer Epidemiology and Risk; BWHS: Black Women's Health Study; CBCS: Carolina Breast Cancer Study; Cl: confidence interval; ER: estrogen receptor; HER2: human epidermal growth factor receptor 2; OC: oral contraceptive; OR: odds ratio; PR: progesterone receptor; TN: triple negative; WCHS: Women's Circle of Health Study.}

\section{Competing interests}

The authors declare that they have no competing interests.

\section{Authors' contributions}

TNB performed the statistical analyses and drafted the manuscript. LR, C-CH, MAT, KLL, EVB, PS, LNK, AFO, and JRP participated in data analysis and interpretation and provided critical feedback. CBA and JRP conceived of the study and participated in the design and coordination of the study. All authors read and approved the final manuscript.

\section{Acknowledgements}

The authors would like to thank the contributing studies' participants and staff. They would also like to acknowledge the late Robert Millikan, DVM, 
$\mathrm{MPH}, \mathrm{PhD}$, who was instrumental in the creation of this consortium. Data on breast cancer pathology were obtained from several state cancer registries (Arizona, California, Colorado, Connecticut, Delaware, District of Columbia, Florida, Georgia, Illinois, Indiana, Kentucky, Louisiana, Maryland,

Massachusetts, Michigan, New Jersey, New York, North Carolina, Oklahoma, Pennsylvania, South Carolina, Tennessee, Texas, Virginia). The results reported do not necessarily represent their views.

The CBCS was approved by the Institutional Review Board at the University of North Carolina at Chapel Hill School of Medicine. The WCHS was approved by the Institutional Review Boards at the University of Medicine and Dentistry of New Jersey (presently Rutgers University), Mount Sinai School of Medicine, and Roswell Park Cancer Institute. The BWHS was approved by the Institutional Review Board at the Boston University School of Medicine.

This research was funded in part by the University Cancer Research Fund of North Carolina (AFO, MAT) and the National Cancer Institute: P01CA151135 (all investigators), P50CA58223 (AFO, MAT), R01CA058420 and UM1CA164974 (TNB, JRP, LR), R01CA100598 (EVB, CBA). The results do not necessarily reflect the views of the sponsors, who had no role in study design; data collection, analysis, or interpretation; or writing and submission of the manuscript.

\section{Author details}

'Slone Epidemiology Center at Boston University, 1010 Commonwealth Avenue, Boston, MA 02215-1201, USA. '2Department of Cancer Prevention and Control, Roswell Park Cancer Institute, Elm \& Carlton Streets, Buffalo, NY 14263, USA. ${ }^{3}$ Department of Epidemiology, University of North Carolina at Chapel Hill, 135 Dauer Drive, McGavran-Greenberg Hall, Campus Box \#7435, Chapel Hill, NC 27599, USA. ${ }^{4}$ Department of Biostatistics, Boston University School of Public Health, Crosstown Center, 801 Massachusetts Avenue, 3rd Floor, Boston, MA 02118, USA. ${ }^{5}$ Cancer Prevention and Control Program, Rutgers Cancer Institute of New Jersey, Rutgers, The State University of New Jersey, 195 Little Albany Street, New Brunswick, NJ 08903, USA. 'Department of Cell, Developmental \& Cancer Biology, Oregon Health \& Science University, Rm RJH 5518 Richard Jones Hall/Mail Code L215, 3181 SW Sam Jackson Park Road, Portland, OR 97239, USA. ${ }^{7}$ Cancer Epidemiology Program, University of Hawai'i Cancer Center, 701 llalo Street, Honolulu, HI 96813, USA.

Received: 29 July 2014 Accepted: 10 February 2015 Published online: 21 February 2015

\section{References}

1. Collaborative Group on Hormonal Factors in Breast Cancer. Breast cancer and hormonal contraceptives: collaborative reanalysis of individual data on 53297 women with breast cancer and 100239 women without breast cancer from 54 epidemiological studies. Lancet. 1996;347:1713-27.

2. Ma H, Wang Y, Sullivan-Halley J, Weiss L, Marchbanks PA, Spirtas R, et al. Use of four biomarkers to evaluate the risk of breast cancer subtypes in the women's contraceptive and reproductive experiences study. Cancer Res. 2010;70:575-87.

3. Marchbanks PA, McDonald JA, Wilson HG, Folger SG, Mandel MG, Daling JR, et al. Oral contraceptives and the risk of breast cancer. N Engl J Med. 2002;346:2025-32.

4. Rosenberg L, Zhang Y, Coogan PF, Strom BL, Palmer JR. A case-control study of oral contraceptive use and incident breast cancer. Am J Epidemiol. 2009:169:473-9.

5. Hunter DJ, Colditz GA, Hankinson SE, Malspeis S, Spiegelman D, Chen W, et al. Oral contraceptive use and breast cancer: a prospective study of young women. Cancer Epidemiol Biomarkers Prev. 2010;19:2496-502.

6. Urban M, Banks E, Egger S, Canfell K, O'Connell D, Beral V, et al. Injectable and oral contraceptive use and cancers of the breast, cervix, ovary, and endometrium in black South African women: case-control study. PLoS Med. 2012;9:e1001182.

7. Kahlenborn C, Modugno F, Potter DM, Severs WB. Oral contraceptive use as a risk factor for premenopausal breast cancer: a meta-analysis. Mayo Clin Proc. 2006:81:1290-302.

8. Huang WY, Newman B, Millikan RC, Schell MJ, Hulka BS, Moorman PG. Hormone-related factors and risk of breast cancer in relation to estrogen receptor and progesterone receptor status. Am J Epidemiol. 2000;151:703-14.

9. Rosenberg L, Boggs DA, Wise LA, Adams-Campbell LL, Palmer JR. Oral contraceptive use and estrogen/progesterone receptor-negative breast cancer among African American women. Cancer Epidemiol Biomarkers Prev. 2010;19:2073-9.

10. Beaber EF, Malone KE, Tang MT, Barlow WE, Porter PL, Daling JR, et al. Oral contraceptives and breast cancer risk overall and by molecular subtype among young women. Cancer Epidemiol Biomarkers Prev. 2014;23:755-64.

11. Kumle M, Weiderpass E, Braaten T, Persson I, Adami HO, Lund E. Use of oral contraceptives and breast cancer risk: The Norwegian-Swedish Women's Lifestyle and Health Cohort Study. Cancer Epidemiol Biomarkers Prev. 2002;11:1375-81.

12. Sweeney C, Giuliano AR, Baumgartner KB, Byers T, Herrick JS, Edwards SL, et al. Oral, injected and implanted contraceptives and breast cancer risk among U.S. Hispanic and non-Hispanic white women. Int J Cancer. 2007:121:2517-23.

13. Van Hoften C, Burger $H$, Peeters PH, Grobbee DE, Van Noord PA, Leufkens HG. Long-term oral contraceptive use increases breast cancer risk in women over 55 years of age: the DOM cohort. Int J Cancer. 2000;87:591-4.

14. Perou CM, Sorlie T, Eisen MB, van de Rijn M, Jeffrey SS, Rees CA, et al. Molecular portraits of human breast tumours. Nature. 2000;406:747-52.

15. Carey LA, Perou CM, Livasy CA, Dressler LG, Cowan D, Conway K, et al. Race, breast cancer subtypes, and survival in the Carolina Breast Cancer Study. JAMA. 2006;295:2492-502.

16. Kaplan HG, Malmgren JA. Impact of triple negative phenotype on breast cancer prognosis. Breast J. 2008;14:456-63.

17. Ooi SL, Martinez ME, Li Cl. Disparities in breast cancer characteristics and outcomes by race/ethnicity. Breast Cancer Res Treat. 2011;127:729-38.

18. Reis-Fillho JS, Tutt AN. Triple negative tumours: a critical review. Histopathology. 2008:52:108-18.

19. Bauer KR, Brown M, Cress RD, Parise CA, Caggiano V. Descriptive analysis of estrogen receptor (ER)-negative, progesterone receptor (PR)-negative, and HER2-negative invasive breast cancer, the so-called triple-negative phenotype: a population-based study from the California Cancer Registry. Cancer. 2007;109:1721-8

20. Yang XR, Chang-Claude J, Goode EL, Couch FJ, Nevanlinna H, Milne RL, et al. Associations of breast cancer risk factors with tumor subtypes: a pooled analysis from the Breast Cancer Association Consortium studies. J Natl Cancer Inst. 2011;103:250-63.

21. Palmer JR, Boggs DA, Wise LA, Ambrosone CB, Adams-Campbell LL, Rosenberg L. Parity and lactation in relation to estrogen receptor negative breast cancer in African American women. Cancer Epidemiol Biomarkers Prev. 2011;20:1883-91.

22. Althuis MD, Fergenbaum JH, Garcia-Closas M, Brinton LA, Madigan MP Sherman ME. Etiology of hormone receptor-defined breast cancer: a systematic review of the literature. Cancer Epidemiol Biomarkers Prev. 2004;13:1558-68.

23. Dolle JM, Daling JR, White E, Brinton LA, Doody DR, Porter PL, et al. Risk factors for triple-negative breast cancer in women under the age of 45 years. Cancer Epidemiol Biomarkers Prev. 2009;18:1157-66.

24. Ritte R, Tikk K, Lukanova A, Tjonneland A, Olsen A, Overvad K, et al. Reproductive factors and risk of hormone receptor positive and negative breast cancer: a cohort study. BMC Cancer. 2013;13:584.

25. Phipps Al, Chlebowski RT, Prentice R, McTiernan A, Wactawski-Wende J, Kuller $\mathrm{LH}$, et al. Reproductive history and oral contraceptive use in relation to risk of triple-negative breast cancer. J Natl Cancer Inst. 2011;103:470-7.

26. Gaudet MM, Press MF, Haile RW, Lynch CF, Glaser SL, Schildkraut J, et al. Risk factors by molecular subtypes of breast cancer across a population-based study of women 56 years or younger. Breast Cancer Res Treat. 2011;130:587-97.

27. Palmer JR, Ambrosone CB, Olshan AF. A collaborative study of the etiology of breast cancer subtypes in African American women: the AMBER consortium. Cancer Causes Control. 2014;25:309-19.

28. Rosenberg L, Adams-Campbell L, Palmer JR. The Black Women's Health Study: a follow-up study for causes and preventions of illness. J Am Med Womens Assoc. 1995;50:56-8

29. Millikan RC, Newman B, Tse CK, Moorman PG, Conway K, Dressler LG, et al. Epidemiology of basal-like breast cancer. Breast Cancer Res Treat. 2008;109:123-39.

30. Ambrosone CB, Ciupak GL, Bandera EV, Jandorf L, Bovbjerg DH, Zirpoli G, et al. Conducting molecular epidemiological research in the Age of HIPAA: a multi-institutional case-control study of breast cancer in African-American and European-American women. J Oncol. 2009;2009:871250.

31. Bandera EV, Chandran U, Zirpoli G, McCann SE, Ciupak G, Ambrosone CB. Rethinking sources of representative controls for the conduct of case-control studies in minority populations. BMC Med Res Methodol. 2013;13:71. 
32. Chandran U, Zirpoli G, Ciupak G, McCann SE, Gong Z, Pawlish K, et al. Racial disparities in red meat and poultry intake and breast cancer risk. Cancer Causes Control. 2013;24:2217-29.

33. International Classification of Diseases for Oncology (ICD-O). Fritz A, Percy C, Jack A, Shanmugaratnam K, Sobin L, Parkin DM, Whelan S. (Eds.). Third Edition, First Revision. World Health Organization, Geneva, Switzerland; 2013.

34. Gapstur SM, Dupuis J, Gann P, Collila S, Winchester DP. Hormone receptor status of breast tumors in black, Hispanic, and non-Hispanic white women An analysis of 13,239 cases. Cancer. 1996;77:1465-71.

35. Parise CA, Bauer KR, Caggiano V. Variation in breast cancer subtypes with age and race/ethnicity. Crit Rev Oncol Hematol. 2010;76:44-52.

36. Ihemelandu CU, Leffall Jr LD, Dewitty RL, Naab TJ, Mezghebe HM, Makambi KH, et al. Molecular breast cancer subtypes in premenopausal and postmenopausal African-American women: age-specific prevalence and survival. J Surg Res. 2007;143:109-18.

37. Higgins JP, Thompson SG. Quantifying heterogeneity in a meta-analysis. Stat Med. 2002:21:1539-58.

38. Dorjgochoo T, Shu XO, Li HL, Qian HZ, Yang G, Cai H, et al. Use of oral contraceptives, intrauterine devices and tubal sterilization and cancer risk in a large prospective study, from 1996 to 2006. Int J Cancer. 2009;124:2442-9.

39. Ursin G, Ross RK, Sullivan-Halley J, Hanisch R, Henderson B, Bernstein L. Use of oral contraceptives and risk of breast cancer in young women. Breast Cancer Res Treat. 1998:50:175-84.

40. Cogliano V, Grosse Y, Baan R, Straif K, Secretan B, El Ghissassi F. Carcinogenicity of combined oestrogen-progestagen contraceptives and menopausal treatment. Lancet Oncol. 2005;6:552-3.

41. Rosenblatt KA, Gao DL, Ray RM, Nelson ZC, Wernli KJ, Li W, et al. Oral contraceptives and the risk of all cancers combined and site-specific cancers in Shanghai. Cancer Causes Control. 2009;20:27-34.

42. Hannaford PC, Selvaraj S, Elliott AM, Angus V, Iversen L, Lee AJ. Cancer risk among users of oral contraceptives: cohort data from the Royal College of General Practitioner's oral contraception study. BMJ. 2007:335:651.

43. Hankinson SE, Colditz GA, Manson JE, Willett WC, Hunter DJ, Stampfer MJ, et al. A prospective study of oral contraceptive use and risk of breast cancer (Nurses' Health Study, United States). Cancer Causes Control. 1997;8:65-72.

44. Ma H, Bernstein L, Ross RK, Ursin G. Hormone-related risk factors for breast cancer in women under age 50 years by estrogen and progesterone receptor status: results from a case-control and a case-case comparison. Breast Cancer Res. 2006;8:R39.

45. Cotterchio M, Kreiger N, Theis B, Sloan M, Bahl S. Hormonal factors and the risk of breast cancer according to estrogen- and progesterone-receptor subgroup. Cancer Epidemiol Biomarkers Prev. 2003;12:1053-60.

46. Bao PP, Shu XO, Gao YT, Zheng Y, Cai H, Deming SL, et al. Association of hormone-related characteristics and breast cancer risk by estrogen receptor/ progesterone receptor status in the shanghai breast cancer study. Am J Epidemiol. 2011;174:661-71.

47. Turkoz FP, Solak M, Petekkaya I, Keskin O, Kertmen N, Sarici F, et al. Association between common risk factors and molecular subtypes in breast cancer patients. Breast. 2013;22:344-50.

48. Iversen A, Thune I, McTiernan A, Emaus A, Finstad SE, Flote V, et al. Ovarian hormones and reproductive risk factors for breast cancer in premenopausal women: the Norwegian EBBA-I study. Hum Reprod. 2011;26:1519-29.

49. Key TJ, Appleby PN, Reeves GK, Roddam AW, Helzlsouer KJ, Alberg AJ, et al. Circulating sex hormones and breast cancer risk factors in postmenopausal women: reanalysis of 13 studies. Br J Cancer. 2011:105:709-22.

50. Merki-Feld GS, Seeger H, Mueck AO. Proliferative effects of estradiol- or ethinylestradiol-progestogen combinations on human breast cancer cells in an intermitted and a long-term regimen. Horm Metab Res. 2012;44:415-21.

51. Isaksson E, von Schoultz E, Odlind V, Soderqvist G, Csemiczky G, Carlstrom K et al. Effects of oral contraceptives on breast epithelial proliferation. Breast Cancer Res Treat. 2001;65:163-9.

52. Gupta PB, Proia D, Cingoz O, Weremowicz J, Naber SP, Weinberg RA, et al. Systemic stromal effects of estrogen promote the growth of estrogen receptor-negative cancers. Cancer Res. 2007;67:2062-71.

53. Campesi I, Sanna M, Zinellu A, Carru C, Rubattu L, Bulzomi P, et al. Oral contraceptives modify DNA methylation and monocyte-derived macrophage function. Biol Sex Differ. 2012;3:4

54. Szyf M, Pakneshan P, Rabbani SA. DNA methylation and breast cancer. Biochem Pharmacol. 2004;68:1187-97.
55. Ravdin PM, Cronin KA, Howlader N, Berg CD, Chlebowski RT, Feuer EJ, et al. The decrease in breast-cancer incidence in 2003 in the United States. N Engl J Med. 2007:356:1670-4.

56. Powles TJ, Hickish T. Breast cancer response to hormone replacement therapy withdrawal. Lancet. 1995;345:1442.

57. Althuis MD, Brogan DD, Coates RJ, Daling JR, Gammon MD, Malone KE, et al. Breast cancers among very young premenopausal women (United States). Cancer Causes Control. 2003:14:151-60.

58. Moorman PG, Millikan RC, Newman B. Oral contraceptives and breast cancer among African-american women and white women. J Natl Med Assoc. 2001;93:329-34

59. Shapiro S, Rosenberg L, Hoffman M, Truter H, Cooper D, Rao S, et al. Risk of breast cancer in relation to the use of injectable progestogen contraceptives and combined estrogen/progestogen contraceptives. Am J Epidemiol. 2000;151:396-403.

60. Sitruk-Ware R, Nath A. Characteristics and metabolic effects of estrogen and progestins contained in oral contraceptive pills. Best Pract Res Clin Endocrinol Metab. 2013;27:13-24.

61. Gerstman BB, Gross TP, Kennedy DL, Bennett RC, Tomita DK, Stadel BV. Trends in the content and use of oral contraceptives in the United States, 1964-88. Am J Public Health. 1991;81:90-6.

62. Althuis MD, Brogan DR, Coates RJ, Daling JR, Gammon MD, Malone KE, et al. Hormonal content and potency of oral contraceptives and breast cancer risk among young women. Br J Cancer. 2003;88:50-7.

63. Beaber EF, Buist DS, Barlow WE, Malone KE, Reed SD, Li Cl. Recent oral contraceptive use by formulation and breast cancer risk among women 20 to 49 years of age. Cancer Res. 2014;74:4078-89.

64. Marchbanks PA, Curtis KM, Mandel MG, Wilson HG, Jeng G, Folger SG, et al. Oral contraceptive formulation and risk of breast cancer. Contraception. 2012;85:342-50

65. Flegal KM, Carroll MD, Kit BK, Ogden CL. Prevalence of obesity and trends in the distribution of body mass index among US adults, 1999-2010. JAMA. 2012:307:491-7.

66. Edelman AB, Cherala G, Munar MY, Dubois B, Mclnnis M, Stanczyk FZ, et al. Prolonged monitoring of ethinyl estradiol and levonorgestrel levels confirms an altered pharmacokinetic profile in obese oral contraceptives users. Contraception. 2013:87:220-6.

67. Edelman AB, Carlson NE, Cherala G, Munar MY, Stouffer RL, Cameron JL, et al. Impact of obesity on oral contraceptive pharmacokinetics and hypothalamic-pituitary-ovarian activity. Contraception. 2009;80:119-27.

68. Edelman AB, Cherala G, Stanczyk FZ. Metabolism and pharmacokinetics of contraceptive steroids in obese women: a review. Contraception. 2010;82:314-23.

69. Ambrosone CB, Zirpoli G, Ruszczyk M, Shankar J, Hong CC, Mcllwain D, et al. Parity and breastfeeding among African-American women: differential effects on breast cancer risk by estrogen receptor status in the Women's Circle of Health Study. Cancer Causes Control. 2014;25:259-65.

70. Bandera EV, Chandran U, Zirpoli G, Gong Z, McCann SE, Hong CC, et al. Body fatness and breast cancer risk in women of African ancestry. BMC Cancer. 2013:13:475

71. Hall IJ, Newman B, Millikan RC, Moorman PG. Body size and breast cancer risk in black women and white women: the Carolina Breast Cancer Study. Am J Epidemiol. 2000:151:754-64

72. Palmer JR, Adams-Campbell LL, Boggs DA, Wise LA, Rosenberg L. A prospective study of body size and breast cancer in black women. Cancer Epidemiol Biomarkers Prev. 2007;16:1795-802.

73. Nischan P, Ebeling K, Thomas DB, Hirsch U. Comparison of recalled and validated oral contraceptive histories. Am J Epidemiol. 1993;138:697-703.

74. Rosenberg MJ, Layde PM, Ory HW, Strauss LT, Rooks JB, Rubin GL. Agreement between women's histories of oral contraceptive use and physician records. Int J Epidemiol. 1983;12:84-7. 